\title{
Vogais NasAis do PoRTUguês BRAsileiro: REFLEXõES PRELIMINARES DE UMA REVISITA
}

\author{
Nasal vowels in Brazilian Portuguese: \\ preliminary considerations in a revisit
}

\author{
Beatriz Raposo de Medeiros*
}

\section{INTRODUÇÃO}

Descrições e interpretações fonéticas e fonológicas do segmento vocálico nasal em português tem se filiado, na lingüística brasileira e mesmo na portuguesa, ao estruturalismo de Mattoso Câmara Jr., para quem o caráter nasal da vogal se deve ao segmento consonântico nasal que a segue e o que o autor chama de arquifonema nasal. O fenômeno consonântico em questão, que doravante chamaremos de murmúrio da vogal nasal ou apenas murmúrio nasal ${ }^{1}$, não é apenas um gesto remanescente do qual a vogal assimila a nasalidade. o murmúrio nasal, muitas vezes, é facilmente visualizado no espectrograma. Um estudo fonético acústico como o de Sousa (1994) pode mostrar isso, tanto com medidas de freqüência, como de duração. Por outro lado, temos evidências, a partir dos dados do presente trabalho, de que o murmúrio nasal encontrado quando a vogal nasal antecede uma consoante oclusiva, não é detectado antes de consoante fricativa. Assim, para que as reflexões frutifiquem é preciso aclarar alguns pontos de partida no estudo das vogais nasais do português brasileiro (doravante PB). De um lado, temos a possível interpretação (como o fez Cagliari, 1977) de que a vogal teria assimilado totalmente a consoante nasal, tornando-se nasalizada, representando-se no nível fonético como apenas um segmento. De outro lado,

Professora Doutora da Universidade de São Paulo.

Esclarecemos que o murmúrio nasal de que tratamos neste texto é diferente do murmúrio nasal de consoantes nasais em ataque de sílaba, evidências a partir do inglês (KRAKOW, 1989) deverão ser discutidas adiante. 
temos estudos fonológicos (ABAURRE; PAGOTTO 1996; BATTISTI, 1998; BISOL, 2002; MORAES; WETZELS, 1992; QUICOLI, 1990), que defendem a existência de uma consoante seguinte à vogal nasalizada. Isto quer dizer que interpretam a hipótese bifonêmica de Mattoso ao pé da letra, atribuindo de fato dois segmentos distintos na realização da vogal nasal. Por fim, temos evidências da realização acústica da vogal nasal de que não se trata de detectarmos fases nitidamente. Detecta-se um contínuo de vogal nasal para um murmúrio nasal (quando este existe), no entanto, é quase impossível estabelecer o início e o fim de cada um, como veremos na seção de análise dos dados fonético-acústicos coletados para as reflexões deste texto.

Entendemos o fenômeno de nasalidade vocálica em português como um fenômeno complexo, por isso difícil de ser explicado. Assim, tanto do ponto de vista da fonética, como da fonologia, muitas questões permanecem sem solução. Os fonólogos, em geral, interpretam as vogais nasais apenas como contrapartes nasalizadas de suas orais e evitam o termo vogal nasal, enquanto trabalhos levados a cabo no âmbito da fonética experimental (exceto Cagliari, 1977) usam o termo vogal para o mesmo fenômeno (SOUSA, 1994; JESUS, 2002; DELVAUX, 2003).

Propomos com estas reflexões levantar: 1) os achados da fonética experimental em torno do fenômeno da nasalidade vocálica e sua contribuição para entendermos melhor sua realização; 2) a questão da variabilidade do murmúrio nasal, variabilidade esta que implica em assumirmos uma representação melhor elaborada para a vogal nasal em PB; 3) a proposta de uma abordagem do fenômeno a partir da Fonologia Articulatória, a qual será apresentada ao final deste texto.

Os resultados deste trabalho, obtidos nos estudos descritos nas seções 5 e 6 , apontam para 1) um espectro dos primeiros pulsos da vogal nasal já influenciados pelo acoplamento dos tubos ${ }^{2}$, o que significa que não existe uma fase puramente oral e 2) a variabilidade acústica da vogal nasal, dependendo do contexto à direita; ou seja, vogais nasais antecedendo consoantes oclusivas apresentam murmúrio nasal e aquelas antes de fricativas, não obrigatoriamente. Isto nos levou a questionar a divisão das fases da vogal nasal, em simplesmente vogal oral e consoante nasal.

\subsection{A Manutenção da Hipótese Bifonêmica é Possível?}

No tocante à hipótese bifonêmica, podemos dizer que esta faz sentido, pois pode-se prever no mínimo duas fases para a vogal nasal, se $o$ 
murmúrio não for detectado: uma fase oralizada, ainda que breve, e outra nasal (CAGLIARI, 1977; SOUSA, 1994). A ressalva a ser feita ao termo "bifonêmica" é que este abriga o conceito de dois fonemas perfeitamente segmentáveis: a vogal e a consoante. Sugerimos, então, o termo bifásico. No entanto, a simples proposta de mudanças de nomenclatura não deve minimizar o insight mattosiano. Assim, a hipótese VN de Mattoso contemplaria a variabilidade da produção da vogal nasal, uma vez que $\mathrm{V}$ representaria a qualidade vocálica e $\mathrm{N}$ abrangeria a porção nasal acrescida ou não do murmúrio nasal.

Vale ressaltar que as porções da vogal nasal não existem independentemente, e assim estamos lidando com apenas um segmento (SOUSA, 1994). Além disso, cabe saber quanto da porção oral é importante como pista da qualidade da vogal para a percepção do falante, e se ela tem a mesma importância e existência em todas as vogais nasais do PB. Por ora, alguns dados de percepção envolvendo discriminação das diferentes fases da vogal nasal (MEDEIROS, 2006) apontam para a percepção do murmúrio nasal vocálico, tanto quanto apontam para a percepção de uma qualidade vocálica, quando o que está em jogo é a fase em que o murmúrio deveria predominar. Isto indica quão variável é a vogal nasal.

\section{As Vogais Nasais Consideradas Para Este Trabalho}

Consideramos vogais nasais do $\mathrm{PB}$ as vogais em sílabas do tipo CVN, e/ou VN, pré-tônicas e tônicas ${ }^{3}$ em que o primeiro C é uma consoante, $\mathrm{V}$ é uma vogal e $\mathrm{N}$, que segue esta última, representa a fase final da vogal nasal. Exemplos destas estruturas silábicas podem ser: canto, senda, intacto,

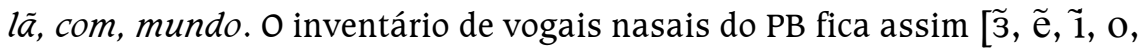

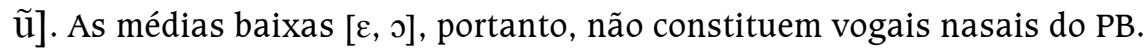
Devemos assinalar que as vogais nasais médias-altas apresentam ditongação, sobretudo a anterior média alta [ẽ], no dialeto paulista da cidade de São Paulo e, por esta razão, podemos argumentar que não são vogais nasais verdadeiras. No entanto não é este o foco deste trabalho.

As pós-tônicas merecem um estudo à parte, por seu comportamento complexo. Dois exemplos desta complexidade: 1) a maioria das pós-tônicas nasais ditonga nesta posição, como é o caso de falam, falem, Milton; 2) [ũ] pode sofrer oralização, como em álbum (/'awbũ/ $\rightarrow[$ 'awbu]) 
Consideramos vogais nasalizadas ${ }^{4}$ aquelas encontradas em sílabas átonas como em banana neste caso o [a] pré-tônico) e em sílabas CV, em que a consoante é uma nasal, como em mata ${ }^{5}$. Entretanto, restringimo-nos a levantar este aspecto como passível de investigação e advertimos, desde já, que não é o objeto deste estudo, embora reconheçamos sua importância para a questão da nasalidade em PB. Ainda na palavra banana, encontramos outro fenômeno de nasalidade que é o da vogal tônica, seguida de consoante nasal, em relação a que nos fazemos a pergunta: trata-se de uma vogal nasal ou apenas nasalizada? Sabemos que as palavras ama e ana (bem como os paradigmas que delas se formam, acrescentando-se uma consoante inicial) apresentam a vogal tônica obrigatoriamente nasalizada, ou seja, não se trata de uma nasalização opcional como no primeiro [a] de banana. Assim, sugerimos, para estudos futuros, uma discussão sobre o fato de tal nasalização ser alofônica, segundo Moraes e Wetzels (1992).

Outro aspecto que merece destaque no estudo da nasalidade vocálica em PB é a ditongação, no entanto, julgamos prudente, em um primeiro momento, concentrarmos a atenção em um só aspecto, e evitarmos lidar com muitas variáveis em um assunto, que só pela natureza do fenômeno envolvido, já é complexo.

Neste sentido, do inventário das vogais nasais do PB, escolhemos três [î, $\left.M, u^{u}\right]$ para serem analisadas acusticamente, como se verá nas seções 5 e 6 .

\section{Estudos Experimentais E a REALIZAÇÃo das Vogais NASAIS}

Antes de nos reportarmos aos trabalhos de Cagliari (1977), Sousa (1994), Jesus (2002) no PB e Delvaux (2003), no francês, é preciso responder, do ponto de vista acústico e articulatório, à questão "O que é uma vogal nasal?". Para a produção de uma vogal nasal, a cavidade oral encontra-se aberta, o véu palatino se abaixa e assim, o ar que fez vibrar as pregas

\footnotetext{
O termo "nasalizada" é empregado por fonólogos que fazem uma distinção entre vogais nasais e aquelas que historicamente foram nasalizadas, pois seguidas de consoantes nasais. Neste sentido, o PB só possuiria vogais nasalizadas no nível fonético, pois no nível subjancente seriam orais. Neste trabalho, o termo "nasalizada" é empregado quando é preciso nos referirmos a vogais orais que sofrem influência de segmentos nasais adjacentes, mas que, por distinvidade fonológica, devem permanecer orais, ou ainda, opcionalmente, podem vir a ser nasais. A questão não é simples, mas evoca uma problemática a ser desvendada no reino da nasalidade vocálica em $\mathrm{PB}$.

Explica-se a nasalização de vogais precedidas por consoantes nasais pelo fato dos movimentos do véu serem graduais, ainda que controlados (CLUMECK, 1976). Dados aerodinâmicos como os de Amelot e Michaud (2006) e articulatórios como os de Oliveira e Teixeira (2007) nos revelam que há um tempo de fechamento do véu sobreposto ao gesto seguinte, nasalizando parcialmente este último gesto.
} 
vocais passa tanto pela cavidade nasal como pela oral. Cria-se o que se chama tradicionalmente na literatura de acoplamento de tubos (o tubo da cavidade oral e o da nasal), cujo resultado acústico é o produto das ressonâncias nasais e orais. As vogais nasais possuem uma qualidade sonora resultante da convivência de ressonâncias e anti-ressonâncias, também chamadas de pólos e zeros, respectivamente. Os pólos e zeros interagem devido ao acoplamento dos tubos e podem produzir: (1) seu próprio cancelamento - caso suas freqüências de ressonância sejam iguais -, havendo perda de energia do espectro; (2) formantes nasais e (3) formantes orais. Uma descrição detalhada do sistema de absorção de ressonâncias gerado pelo acoplamento, bem como a descrição das ressonâncias das cavidades nasais e sua interação com as ressonâncias do trato oral encontrase em Stevens (2000).

Assim como os resultados acústicos são originados de um sistema de filtragem de ressonâncias bastante intrincado, o movimento do véu palatino também oferece complexidade, uma vez que não se trata de opor uma posição aberta à outra fechada. Segundo estudo eletromiográfico de Ushijima e Hirose (1974), com dados do japonês, a nasal de coda em / teNteNteN/ apresentou maior rapidez no abaixamento do véu do que a consoante de ataque em /nenene/. Achados sobre o movimento do véu, através de cinefluorografia, (KENT; CARNEY; SEVEREID, 1974), incluem a elevação inicial deste em seqüência VNC, antes da constrição oral para a consoante nasal, em inglês americano. Assim, vê-se que o fenômeno da nasalidade, seja da vogal ou da consoante, apresenta uma variabilidade no movimento articulatório do véu, que é controlado para seu maior ou menor abaixamento. Veremos a seguir alguns achados sobre o posicionamento do véu palatino para a vogal nasal especificamente.

Trabalhos de natureza experimental, tomando o fenômeno da nasalidade no $\mathrm{PB}$, são unânimes quanto à complexidade do assunto $\mathrm{e}$ esclarecem-nos a produção acústica e articulatória dos segmentos nasais e/ ou nasalizados, como é o caso de Cagliari (1977), que desenvolve uma pesquisa bastante abrangente do fenômeno em $\mathrm{PB}$, incluindo em seus dados, a fala de vozes normais e de nasalidade patológica (ou seja, que atinge até os segmentos orais). Para tanto, o autor realiza experimentos acústicos, articulatórios e aerodinâmicos e, nestes dois últimos, utiliza recursos como laringografia, fluorografia e pneumotacografia. Sousa (1994) faz uma caracterização das acústicas das vogais nasais do PB, com detalhes, e Jesus (2002), também em estudo fonético acústico, chega a resultados que corroboram os de Sousa (1994). Delvaux (2003) trata das vogais nasais do francês, avaliando aspectos articulatórios e acústicos, incluindo também 
aspectos perceptuais das vogais estudadas. Alguns de seus resultados acústicos vão ao encontro dos resultados obtidos por Sousa (1994).

Retomando a questão da complexidade do fenômeno, vejamos como podemos exemplificá-la a partir de dois dos autores já citados. Cagliari (1977) e Delvaux (2003) apontam para diferentes graus de nasalidade, dependendo do grau de abaixamento do véu palatino. O primeiro autor ressalta que a razão oral:nasal, ou seja, as diferenças de dimensão entre as cavidades oral e nasal, modificadas pelo maior ou menor abaixamento do véu palatino, é responsável pelo grau de nasalidade de um som da fala. Cagliari (1977) postula cinco parâmetros envolvidos na produção da nasalidade: abertura nasal, altura do véu, características do fluxo de ar, acoplamento acústico, coordenação do traço oral/nasal. Dado que a nasalidade é fruto das ressonâncias do tubo nasal (da cavidade nasal que se acopla à oral, ou não, no caso das consoantes), ressaltamos a importância de saber como se realiza o fluxo de ar, quando há abaixamento do véu. A partir de um experimento em que se combinaram técnicas de fluorografia, pneumotacografia e laringografia, foi possível ver o movimento do véu e ter um gráfico do fluxo de ar nasal de segmentos como os da frase Com os leões não se brinca assim. Sobre os resultados deste experimento, Cagliari (1977, p. 278) afirma: "The velic port does not assume only two positions: one open and the other closed. The velum assumes different positions for different speech segments because of the functional need for controlling nasality precisely".

A este achado de Cagliari (1977), podemos relacionar a descrição de dados acústicos do inglês por Stevens (2000) quanto à nasalidade de diferentes vogais produzidas por um falante masculino. As vogais $[\varepsilon]$ e [0] apresentam maior e menor nasalização, respectivamente, o que se deve, segundo Stevens (2000), ao controle da abertura velofaríngea, entre outros fatores, como diferença anatômica individual. Vê-se, então, que os diferentes graus de abertura do véu estão presentes em diferentes línguas (japonês, português, inglês), indicando que o gesto nasal, seja para a vogal, seja para a consoante, realiza-se satisfazendo exigências específicas de cada língua no tocante à distintividade fonológica.

Delvaux (2003) desenvolveu quatro estudos experimentais sobre as vogais nasais do francês: um estudo articulatório, um aerodinâmico, um acústico do ponto de vista da produção e outro do ponto de vista da percepção. Em sua investigação articulatória, a autora mostra, através de imagens de ressonância magnética (MRI), que o abaixamento do véu é

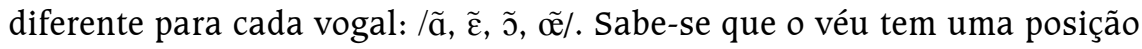
intrinsecamente mais baixa para vogais baixas e que isso se deveria à posição relaxada do palatoglossus na produção destas vogais (MOLL, 1962; MOLL; 
SHRINER, 1967; apud DELVAUX, 2003). Assim, Delvaux verificou que, de modo geral, o véu abaixa-se mais em /ãa em comparação a /̃̃/ e mantém uma posição intermediária para / $/ \tilde{\varepsilon} / \mathrm{e} / \tilde{\mathfrak{e}} /$. O interessante do achado de Delvaux é que, correlacionando-se o grau de abertura do véu com o DAN (débito de ar nasal) de cada vogal, verificou-se que o fluxo de ar nasal é menor na produção de /ãa/ do que na de /̃̃/. Esses fatos indicam quão complexos são os aspectos de produção fonética de uma vogal nasal.

Passamos a apresentar as conclusões sobre a caracterização acústica das vogais nasais a que os autores (Cagliari, 1977; Sousa, 1994; Jesus, 2002 para o PB; Delvaux, 2003 para o francês) chegaram em seus estudos. Muito embora aspectos importantes de articulação e aerodinâmica (fluxo de ar nasal/oral) possam nos dar respostas valiosas para a questão da nasalidade, não receberão o mesmo destaque, por ora, uma vez que a literatura sobre assunto com dados do $\mathrm{PB}$, tem pouco ainda a dizer ${ }^{6}$. Diante do que, resolvemos realizar um estudo acústico, cujo piloto apresentaremos a seguir, a fim de alicerçar, juntamente com os trabalhos experimentais já existentes a nossa argumentação.

Em sua investigação acústica, Cagliari (1977) contemplou sete vogais [i, e, $\varepsilon, a, \rho, o, u]$ e mais as reduzidas [I, $\mathrm{u}]$ para compará-las com as correspondentes nasais, exceto no caso das médias-baixas no aspecto das freqüências de formantes. As vogais, tanto as orais quanto as nasais, inseriam-se em monossílabos. Dentre os resultados de cada um dos três informantes falantes do PB, interessa-nos, por ora, obter uma média para os dois primeiros formantes das seguintes vogais: [i], [a] e [u] e suas contrapartes nasais. Para tanto, apresentamos a tabela abaixo para facilitar a leitura.

TABela 1: MÉdias ObTIDAS DAS MEdidAs EM HERTZ, DE CAGLIARI (1977).

\begin{tabular}{ccccccc}
\hline & {$[\mathrm{i}]$} & {$[\tilde{1}]$} & {$[\mathrm{a}]$} & {$[\tilde{\varepsilon}]$} & {$[\mathrm{u}]$} & {$[\tilde{\mathrm{u}}]$} \\
\hline $\mathrm{F}_{1}$ & 270 & 270 & 620 & 500 & 280 & 250 \\
$\mathrm{~F}_{2}$ & 2190 & 2600 & 1320 & 1425 & 870 & 800 \\
\hline
\end{tabular}

Como veremos logo a seguir, as medidas obtidas por Cagliari (1977) apresentam resultado semelhante àqueles de Sousa (1994) e Jesus (2002), os quais se coadunam também com os nossos (ver seção sobre a vogal nasal e a consoante oclusiva). Nos dados de Cagliari (1977) há diferença de $120 \mathrm{~Hz}$ entre $o F_{1}$ de [3] e o $F_{1}$ de sua oral correspondente [a] e uma diferença de $410 \mathrm{~Hz}$ entre $\mathrm{o} \mathrm{F}_{2}$ de [i] e [i]. A vogal nasal baixa é aquela que apresenta

Há um trabalho de Medeiros e Demolin em que pode-se ver o movimento do véu em vogais nasais do $\mathrm{PB}$, através da técnica de IRM. 
$\mathrm{F}_{1}$ sempre menor que o da sua contraparte oral, indicando elevação da mandíbula, o que não ocorre com as vogais altas das duas extremidades superiores do triângulo vocálico.

Ainda no tocante ao padrão formântico das vogais nasais, vejamos os resultados de duas autoras brasileiras. Sousa (1994) investigou os

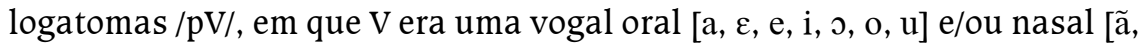
ê, î, õ, ũ]. Os logatomas inseriam-se na frase veículo "Digo __ para ele" que foi falada por quatro sujeitos masculinos do PB. As médias apresentadas pela autora nas tabelas comparativas por vogal oral e nasal são as seguintes no que diz respeito a $\mathrm{F}_{1}: 738 \mathrm{~Hz}$ para [a] x 630 para [̃̃]; $291 \mathrm{~Hz}$ para [i] e 279 para [i]; $299 \mathrm{~Hz}$ para [u] e 310 para [ũ]. As vogais [i] e [ũ] apresentaram, respectivamente, aumento de $\mathrm{F}_{2}$ e $\mathrm{F}_{3}$ em relação a [i] e [u]. Jesus (2002) investigou o padrão masculino e feminino separadamente, encontrando sempre a diminuição de $\mathrm{F}_{1}$ da vogal baixa nasal (canta) em relação a [a] de cata. A média de $\mathrm{F}_{1}$ de falantes masculinos ficou em $680 \mathrm{~Hz}$ para [a], enquanto para $F_{1}$ de [3] ficou em $502 \mathrm{~Hz}$. A autora ainda verificou elevação de $F_{2}$ de [i] em relação a [i] e elevação também de $\mathrm{F}_{3}$ de [ũ] em comparação a [u].

Quanto aos resultados gerais do estudo acústico de Delvaux (2003), podemos dizer que são muito semelhantes aos de Sousa (1994). Argumentando em favor de uma execução não automática ${ }^{7}$ da produção das vogais nasais, Delvaux (2003) conclui que o crescimento da gravidade na vogal nasal em relação à sua contraparte oral, é responsável pela percepção da nasalidade. Os seguintes aspectos acústicos são evidenciados pela autora ao fim do estudo acústico: comparadas às orais, as vogais nasais são mais longas; o véu palatino tem abaixamento maior ou menor, dependendo do contexto fonológico; uma porção oral inicial rapidamente evolui para nasal, e aí, a energia é sempre inferior, afetando, sobretudo a região de $\mathrm{F}_{1}$ e $\mathrm{F}_{3}$. Sousa (1994) chega exatamente às mesmas conclusões no que diz respeito às características acústicas das vogais nasais do $\mathrm{PB}, \mathrm{com} a$ exceção de verificar menor intensidade junto a $\mathrm{F}_{2}$. A autora brasileira ainda destaca a existência e o papel do murmúrio nasal como fase característica da vogal nasal, e que não existe independente dela, assim como acontece com a fase oral.

A compreensão do fenômeno da nasalidade vocálica se dá passando em revista, como fizemos nesta seção, o acoplamento dos tubos, os movimentos do véu palatino e a não linearidade entre os eventos aerodinâmicos, e o resultado acústico a que se chegou nos estudos brasileiros. Esses últimos, porém, não discutem a variabilidade da vogal nasal, o que

Delvaux conclui sua tese dizendo que o modelo da fonética controlada (KINGSTON; DIEHL, 1994) é o melhor para dar conta das vogais nasais no francês. Não é do escopo deste trabalho discutir tal modelo por ora. 
acaba por subdimensionar o fenômeno. Tais estudos também não focam a borda direita, utilizando apenas dados com consoantes oclusivas seguintes à vogal nasal; e não perscrutam sua borda esquerda, perpetuando a descrição de que a vogal nasal possui os primeiros pulsos orais. O presente trabalho propõe desvendar tais problemáticas e dar um tratamento teórico que considere o aspecto dinâmico da vogal nasal.

\section{Um Padrão Acústico Para As Vogais NasAis Do PB}

Diante dos resultados numéricos apresentados acima, é possível delinear um perfil do padrão formântico das vogais nasais extremas do PB, em posição tônica, ressaltando a característica robusta do [ร̃] apresentar seu primeiro formante sistematicamente de 100 a $200 \mathrm{~Hz}$ abaixo do primeiro formante de [a]. É sistemático também o comportamento do segundo formante de [i] - este se eleva em relação ao $F_{2}$ de [i] - e o terceiro de [ũ], que se abaixa em relação a [u]. Obviamente estamos limitando a apresentação dos dados de cada estudo - embora seus desenhos experimentais sejam muito parecidos, mas não se reduzam a um só experimento - para podermos ser mais objetivos ao falar da comparação das vogais orais e nasais; comparação típica em estudos da nasalidade vocálica. Além da comparação de valores de formantes, podemos ter uma caracterização acústica mais completa das vogais nasais, conforme veremos a seguir. Os estudos sobre as vogais nasais do PB nos fornecem suficientes evidências para falarmos de qualidade vocálica, daí a importância de chamar-se a atenção para o padrão acústico. Apesar de ser um gesto complexo, variando ao longo do tempo articulatoria e acusticamente, a vogal nasal mantém seu timbre, a fim de distinguir-se das outras nasais. Isto é indício de quanto orquestramos finamente os articuladores envolvidos na produção do gesto vocálico nasal.

Embora os resultados apresentados indiquem nitidamente um padrão geral entre indivíduos falantes do PB para distinguir acusticamente as vogais orais e nasais, as diferenças individuais sempre são apontadas em investigações experimentais. Por exemplo, em seus dados, Sousa (1994) encontrou, dentre seus quatro informantes masculinos, um que produzia vogais nasais com murmúrios muito curtos, ou mesmo inexistentes. Quanto à trajetória dos formantes das vogais nasais, esta autora investigou minuciosamente o que ocorria junto a cada vogal e falante. Inicialmente levantou os aspectos desta trajetória - que dificultam a visualização dos formantes e a medição destes - e em seguida observou que tais aspectos são detectados junto a um falante e não em outro, dependendo da região de freqüência. Tais aspectos são: interrupção de formante, cluster, bifurcação, 
junção e queda de intensidade e presença de formantes nasais entre os formantes especificados. Sabemos que diferenças individuais podem ser atribuídas a diferentes tipos de voz, cujo articulador responsável é a laringe, mas além disso, quando se fala em segmentos nasais ou nasalizados, há que se levar em conta ainda o fato de haver diferença de um trato nasal para outro, entre indivíduos. Obviamente, isso acarretará diferença no produto de ressonâncias, por exemplo, o fato destas serem mais amortecidas, oferecendo a qualidade nasal à nossa percepção. No entanto, essas diferenças parecem ser neutralizadas pelos falantes, pois, como vimos, eles atingem a distinção oral/nasal de maneira eficiente, uma vez que acabam produzindo dois padrões formânticos sistematicamente distintos: o das vogais orais e das vogais nasais.

No tocante à existência de uma consoante após a vogal nasal, os autores brasileiros reportam o seguinte:

\begin{abstract}
A homorganic nasal consonant does not normally occur following a nasalized vowel and preceding an oral consonant in connected speech. When a homorganic nasal does occur before a stop, it is very short and shows only a very small excursion from the baseline of the nasal traces (CAGLIARI, 1977, p. 304).

A maior parte das vogais nasais analisadas registrou a presença de um murmúrio nasal, que consideramos aqui como constituindo a terceira fase de realização destas vogais. Este murmúrio seria consideravelmente coarticulado à vogal e não apresenta sinais aparentes de transições para um ponto de articulação consonantal (SOUSA, 1994, p. 127).

Neste trabalho, a ocorrência de forma assistemática e bastante heterogênea nos chamou a atenção, levando-nos a especular se este seria condicionado pela vogal, pelo falante ou se haveria um condicionamento dialetal. [...] O murmúrio nasal apresentou-se com freqüência baixa, não se observando informações espectrais que evidenciassem transição para a consoante seguinte (JESUS, 2002, p. 217).
\end{abstract}

Vemos assim, que as abordagens experimentais das vogais nasais do PB não atestam a consoante que, segundo alguns estudos, teria o mesmo ponto de articulação da consoante de onset da sílaba seguinte.

\title{
5 A Vogal nasal E O ConteXto Silábico Seguido De Consoante OCLUSIVA
}

O estudo tratado nesta seção baseou-se nos estudos já existentes na literatura e corrobora o padrão formântico da vogal nasal em PB. As 
vogais-alvo foram [ $\tilde{1}, \tilde{3}$, ũ ] e suas contrapartes orais. Para a coleta dos dados, os pares mínimos cito/cinto; ata/anta e juta/junta foram proferidos em uma frase-veículo (Diga ___ baixinho) por um falante masculino (doravante C.), em cabine insonorizada ${ }^{8}$. Houve cinco repetiçóes de cada palavra contendo as vogais-alvo, a fim de se calcular a média, desvio padrão e o coeficiente de variação relativos aos valores dos formantes. Mediram-se os três primeiros formantes de cada vogal. A tabela abaixo demonstra a tendência já evidenciada (ver seção sobre padrão formântico da vogal nasal) de a vogal baixa nasal apresentar $F_{1}$ cerca de $200 \mathrm{~Hz}$ mais baixo do que a baixa oral e da vogal alta anterior nasal apresentar $F_{2}$ mais alto que sua contraparte oral.

TABEla 2: $\mathrm{F}_{1} \mathrm{E}_{2}$ DAS Vogais NASAIS EXTREMAS E SUAS CONTRAPARTES ORAIS DITAS POR C.

\begin{tabular}{cccc|cccc}
\hline & {$[\tilde{1}]$} & {$[\tilde{3}]$} & {$[\tilde{\mathrm{u}}]$} & & {$[\mathrm{i}]$} & {$[\mathrm{a}]$} & {$[\mathrm{u}]$} \\
\hline $\mathrm{F}_{1}$ & 367 & 443 & 392 & $\mathrm{~F}_{1}$ & 318 & 685 & 377 \\
$\mathrm{DP}$ & 32 & 46 & 35 & $\mathrm{DP}$ & 17 & 21 & 25 \\
$\mathrm{CV}$ & 8,7 & 10 & 8,9 & $\mathrm{CV}$ & 5,3 & 3 & 6,6 \\
$\mathrm{~F}_{2}$ & 2380 & 1393 & - & $\mathrm{F}_{2}$ & 2197 & 1335 & 920 \\
$\mathrm{DP}$ & 140 & 37 & - & $\mathrm{DP}$ & 56 & 33 & 51 \\
$\mathrm{CV}$ & 5,8 & 2,6 & - & $\mathrm{CV}$ & 2,5 & 2,5 & 5,5 \\
$\mathrm{~F}_{3}$ & - & 2763 & 2442 & $\mathrm{~F} 3$ & 3104 & 2460 & - \\
$\mathrm{DP}$ & - & 237 & 332 & $\mathrm{DP}$ & 244 & 18 & - \\
$\mathrm{CV}$ & - & 8,7 & 13,5 & $\mathrm{CV}$ & 7,9 & 0,73 & - \\
\hline
\end{tabular}

DP (desvio padrão em Hz) e CV (coeficiente de variação) indicam pouca variabilidade dos dados.

A vogal nasal alta posterior apresentou em todas as repetições pouca energia na região de freqüência de $\mathrm{F}_{2}$, tornando impossível medir este formante. Junto a [ $\tilde{3}$ ] e [ u ], $\mathrm{F}_{3}$ detectava-se facilmente, o que não acontecia com a vogal nasal anterior. No caso desta última, muito provavelmente, $\mathrm{F}_{3}$ formava um cluster com o $F_{2}$, que se apresentou sistematicamente elevado em relação à vogal oral. 
Analisamos ainda o comportamento inicial da vogal nasal, gerando um espectro FFT, a fim de verificar se este era mais semelhante ao espectro da vogal oral ou ao da nasal. Para tanto, escolhemos espectrogramas e formas de onda ${ }^{9}$ que ilustravam bem os fenômenos de que estamos tratando no presente trabalho e geramos três espectros FFT a partir de cada vogal: um espectro de 4 a 5 pulsos iniciais, outro de mesmo número de pulsos a partir da porção medial para as vogais nasais, e um terceiro espectro da porção medial da vogal oral, também com 4 ou 5 pulsos. $O$ resultado pode ser visto nas figuras a seguir.

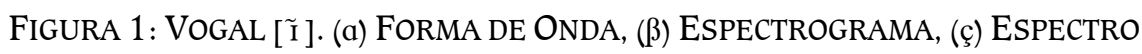
DA Porção Inicial da Vogal, (ð) EsPectro da Porção MEdial dA Vogal. LinHas PONTILHADAS EM (ß), (ç) E (ð) COM UNIDADE ESCALAR DE $800 \mathrm{HZ.}$
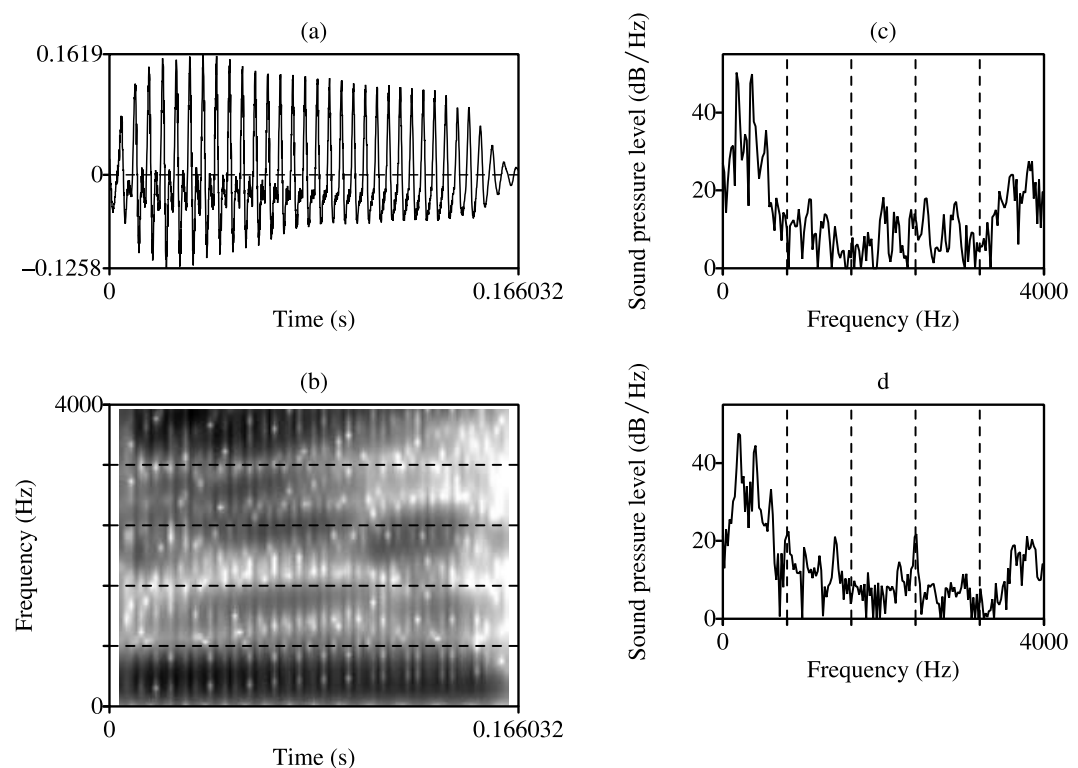

$$
\text { Time (s) }
$$


Figura 2: VOGAL [ I ]. (a) FORMA DE ONDA, ( $\beta$ ) EsPECTROGRAMA, (ç) EsPECTRO DA Porção Inicial da Vogal. Linhas Pontilhadas EM (ß) E (ç) COM UNIDADE ESCALAR DE $800 \mathrm{HZ}$.
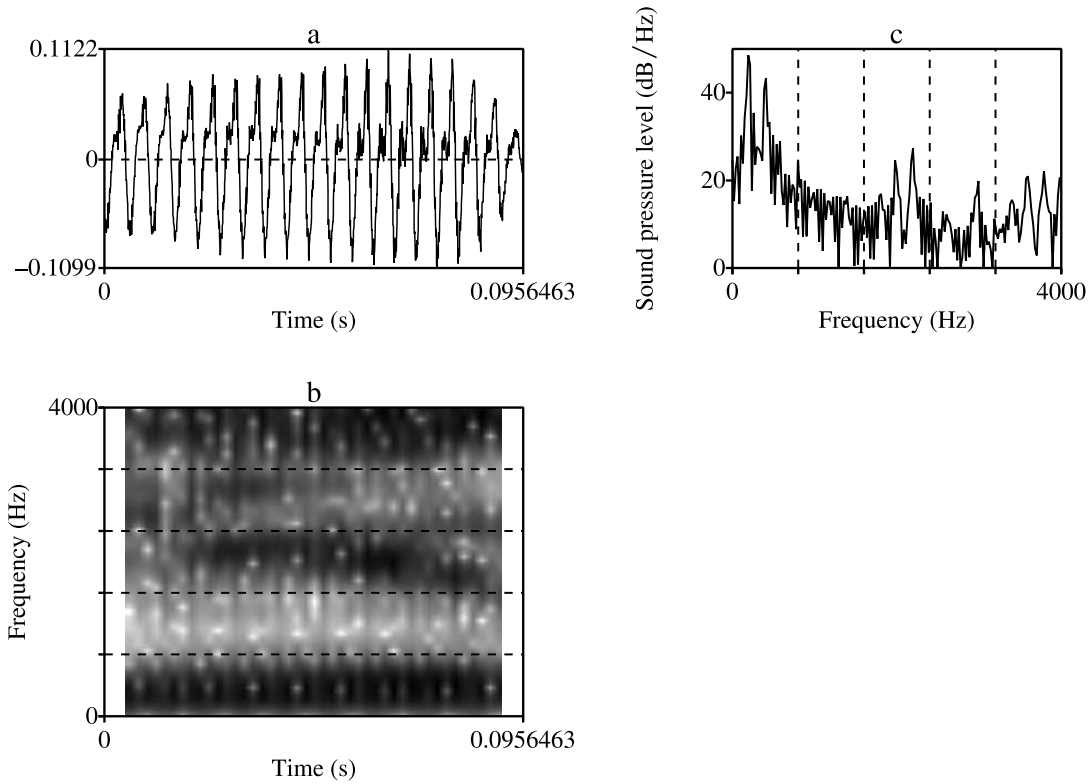

FIGURA 3: VOGAL [ ̃ ] ]. (a) FORMA DE ONDA, ( $\beta$ ) ESPECTROGRAMA, (ç) ESPECTRO

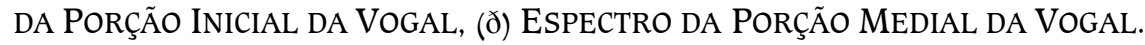
LiNHAS PonTILHADAS EM (ß), (ç) E (ð) COM UNIDADE ESCALAR DE $800 \mathrm{HZ}$.
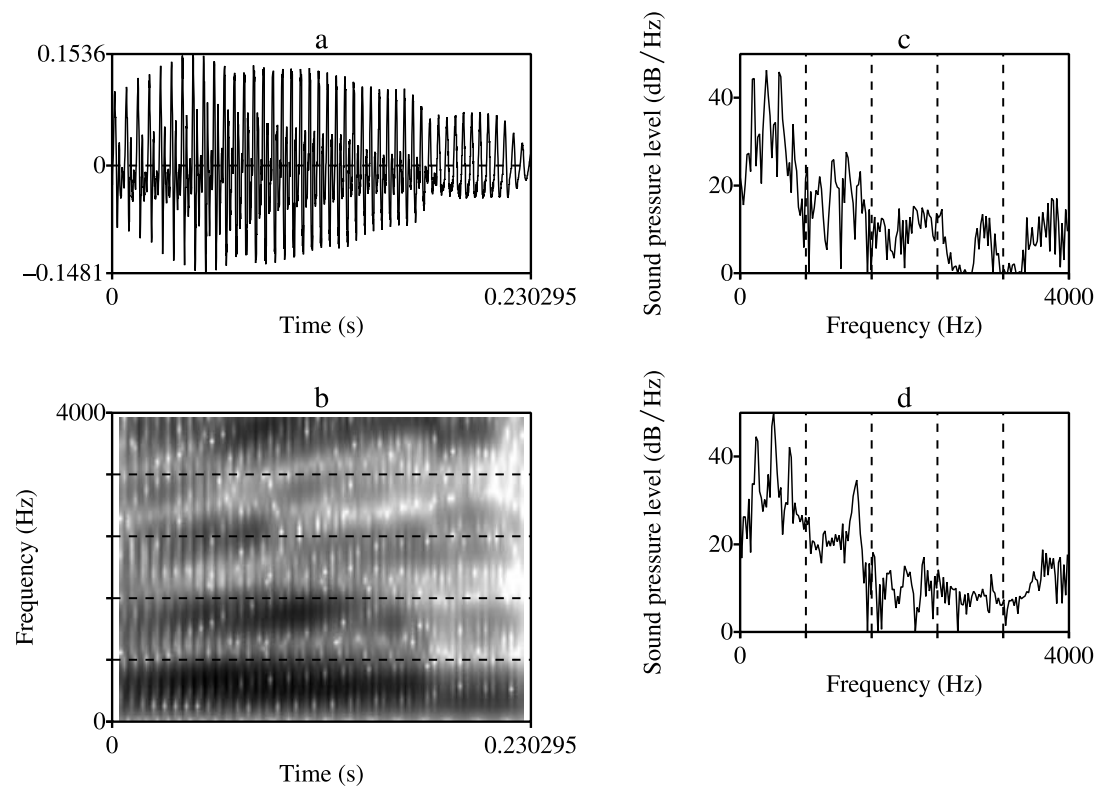
Figura 4: Vogal [ a]. (a) Forma DE ONDA, ( $\beta$ ) ESPECTROGRAMA, (c) ESPECTRO Da Porção Inicial da Vogal. Linhas Pontilhadas EM (b) E (c) COM UNIDADE ESCALAR DE $800 \mathrm{HZ}$.
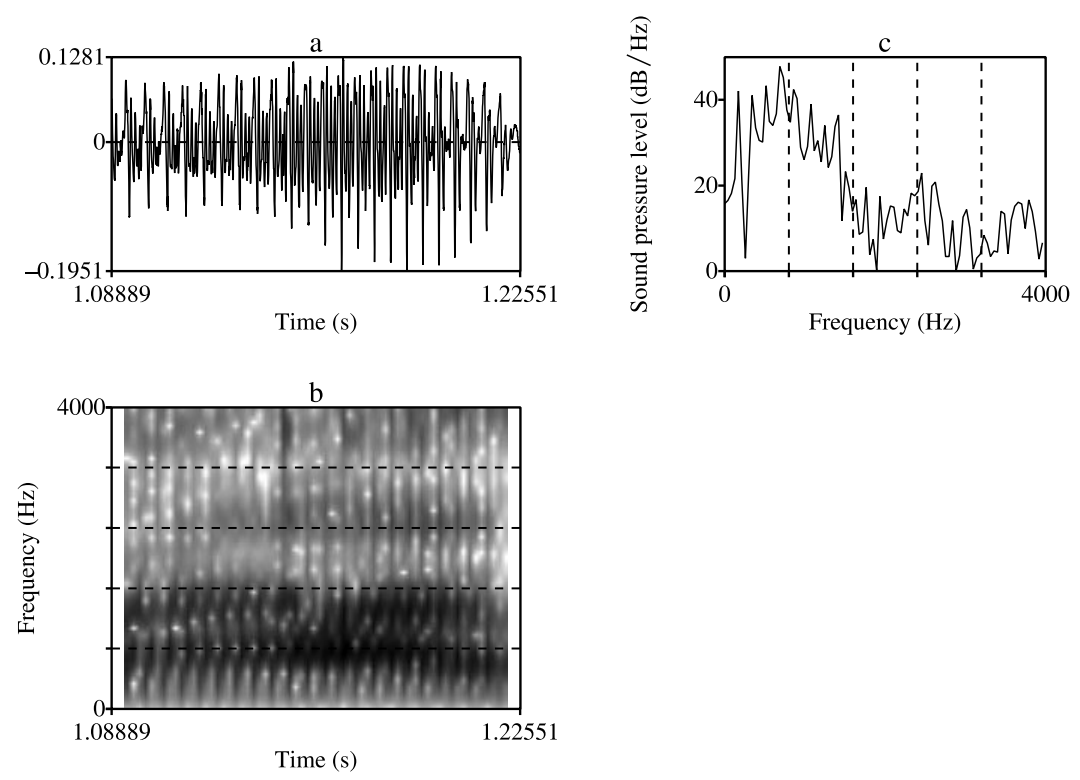

Figura 5: VogAL [ $\tilde{u}$ ]. (a) ForMA DE ONDA, (b) ESPECTROGRAMA, (c) ESPECTRO DA Porção INICIAL DA Vogal, (d) EsPectro da Porção MEdial dA Vogal. LinHAS PonTILHADAS EM (b), (c) E (d) COM UNIDADE ESCALAR DE 800 HZ.
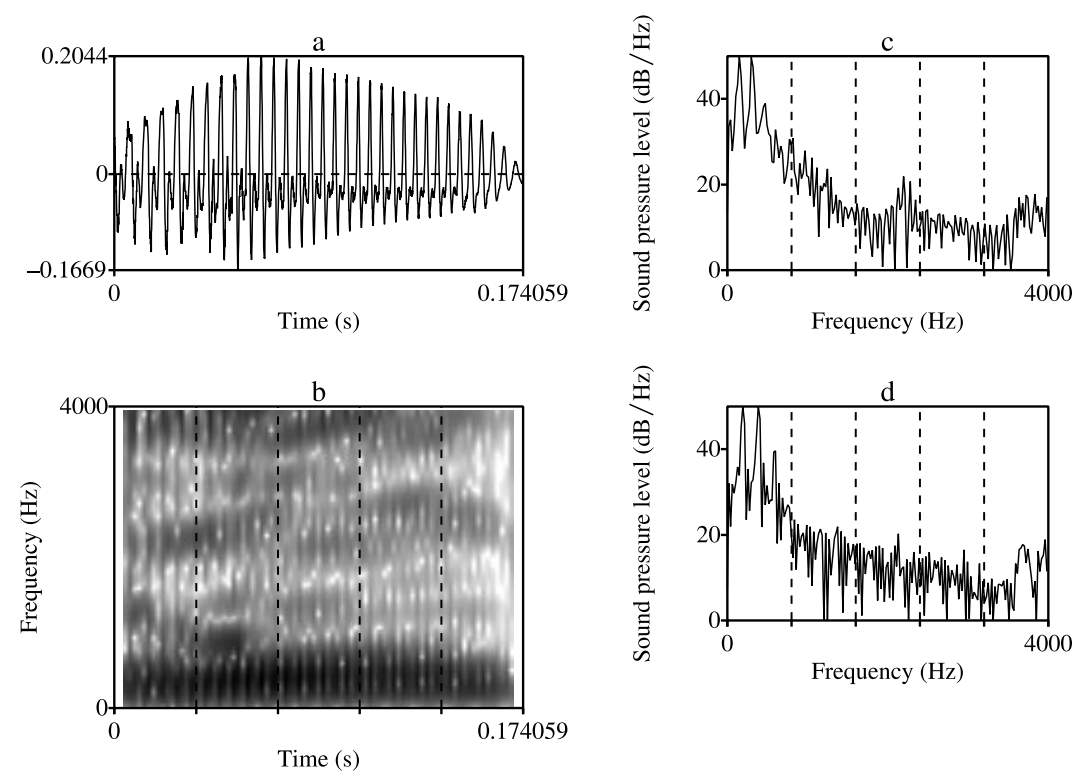
Figura 6: Vogal [ u ]. (a) Forma DE OndA, (b) ESPECTROGRAma, (c)

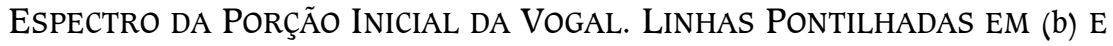
(c) COM UNIDADE ESCALAR DE $800 \mathrm{HZ}$.
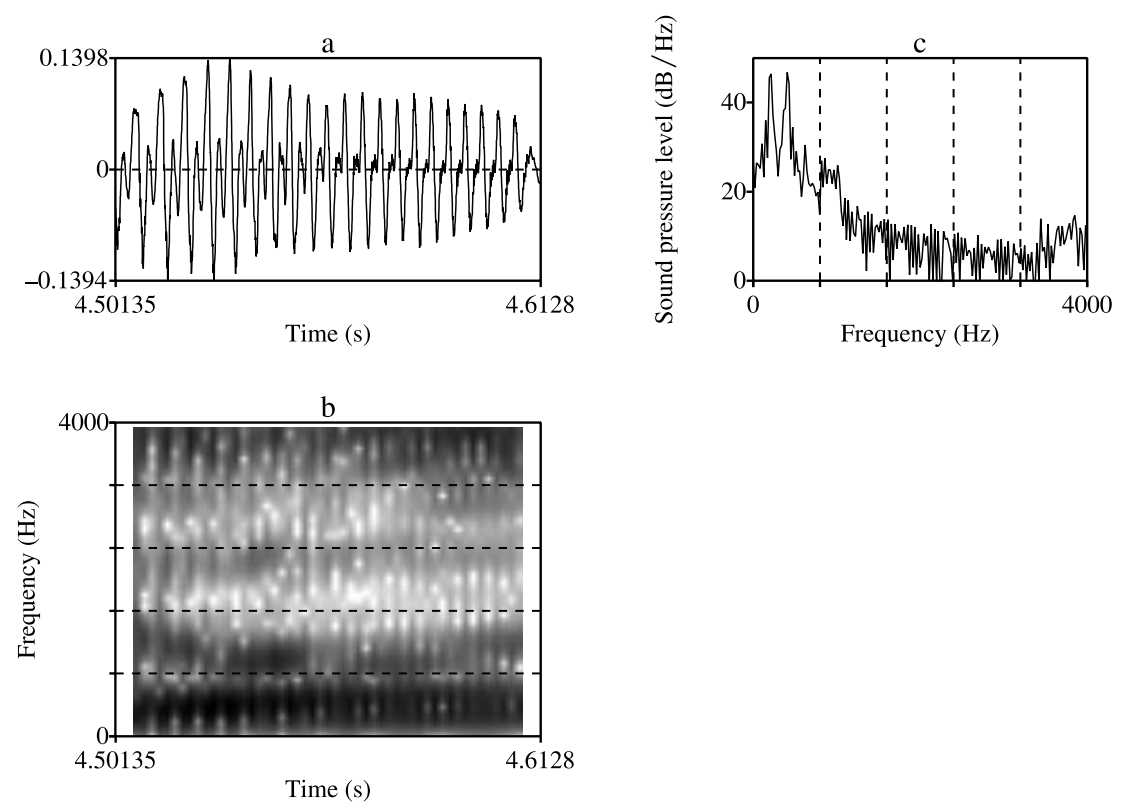

\subsection{COMPARAÇÃo ESPECTRAL ENTRE [ [ i ] E [ i ]}

O que melhor diferencia os espectros em comparação (Figura $1 \mathrm{~d}$ e Figura 2 c) é a presença de um formante nasal por volta de $800 \mathrm{~Hz}$, outro por volta de $1400 \mathrm{~Hz}$ e o deslocamento de $\mathrm{F}_{2}$ para $2400 \mathrm{~Hz}$, que como já vimos é a elevação deste formante em relação ao $\mathrm{F}_{2}$ da vogal oral. Quanto à porção inicial (Figura $1 \mathrm{c}$ ), esta não apresenta formantes nasais, mas um aglomerado de picos de baixa amplitude, em torno da região que seria de $\mathrm{F}_{2}$ nasal. Já a vogal oral apresenta $F_{2}$ por volta de $2200 \mathrm{~Hz}$, destacado dos harmônicos de pouca amplitude que o precedem.

\subsection{COMPARAÇÃo ESPECTRAL ENTRE [ ว̃ ] E [ a ]}

A visualização dos espectros da vogais baixas nasal e oral na porção medial indica maior número de picos em torno de $\mathrm{F}_{1}$ para [a] do que para [ $\tilde{3}$ ]. $F_{2}$ de [ $\tilde{3}$ ] encontra-se destacado de $F_{1}$ por um vale na faixa de 700 a $1300 \mathrm{~Hz}$. Há presença de vale, também, na região de freqüência que corresponderia a $_{3}$ oral. Em seu estudo sobre as vogais nasais do PB, 
Seara (2000) considera os vales nos espectros como representativos das anti-ressonâncias, que são características destas vogais. Destaca-se, ao final da vogal nasal (ver forma de onda e espectrograma), o murmúrio nasal. Este, embora comum antes de consoantes oclusivas, não se encontra tão nitidamente nas demais vogais deste estudo. A porção inicial de [ [̃ ] também apresenta poucos picos em torno de $\mathrm{F}_{1}$, o que indica aumento de largura de banda dos harmônicos, e um vale acentuado na região de $\mathrm{F}_{3}$. Assim, este é um espectro semelhante ao espectro nasal.

\subsection{COMPARAÇÃo ESPECTRAL ENTRE [ ũ ] E [ u ]}

As diferenças encontradas entre os espectros de FFT de [ [ u ] e [ u ] na porção medial não são muito grandes. No entanto, percebe-se o destacamento de um pico por volta de $600 \mathrm{~Hz}$ (formante nasal) na vogal nasal e grande perda de energia nos picos próximos de $940 \mathrm{~Hz}$, valor correspondente a $\mathrm{F}_{2}$ da vogal posterior oral. A porção inicial da posterior nasal assemelha-se aos outros espectros em comparação, mas assim como a porção medial da nasal, apresenta picos de pouca amplitude na região de $\mathrm{F}_{2}(940 \mathrm{~Hz})$.

As comparações acima, por meio de espectros vocálicos baseiamse em comparações semelhantes de Stevens (2000), que elenca o aumento de largura de banda, perda de proeminência dos picos e presença de formantes nasais como pistas da nasalidade. Comparando [a a ] e [a ], por exemplo, da palavra engage (francês), Stevens (2000) também, assim como ocorre com as vogais baixas deste estudo, encontra picos espectrais mais destacados em torno dos dois primeiros formantes na vogal oral. Aspectos típicos da vogal nasal, como aumento de largura de banda, vales e formantes nasais foram encontrados nas duas porções, inicial e medial, das vogais nasais investigadas.

Assim, através das comparações feitas, concluímos que a porção inicial da vogal nasal não é tão diferente da medial, indicando que o véu deve estar abaixado desde o início da vogal. Daí considerarmos mais apropriado chamar o início da vogal nasal de oralizada e não de oral. Ainda assim, tal designação remete à idéia de uma fase definida em relação à outra. No entanto, temos evidências neste estudo e no próximo (seção 5) de que a variabilidade da vogal nasal não permite estabelecer, sequer generalizar, fases, que antes, dependem da qualidade vocálica e do contexto. A direção tomada, até aqui, é a de que a representação do gesto vocálico nasal tem de ser elástica; podendo ora aceitar maior nasalidade, ora menor nasalidade em sua borda esquerda. 


\section{A Vogal nasal e o Contexto Silábico Seguido de Consoante FRICATIVA}

Este estudo vem complementar os estudos experimentais já existentes, que analisam a vogal nasal antes de consoante oclusiva. Para isso, o falante masculino B. proferiu as seguintes palavras gravadas na cabine insonorizada do Laboratório de Fonética da USP: tampa/âmbar, canta/ anda, panca/tanga, anfi; dança/transa, cancha/canja; limpa/timbre, pinta/ inda, finca/íngua, infra, pinça/quinze, pincha/finja; cumpra/rumba, punta/ fundo, junco/fungo e punge. A frase-veículo foi Eu digo __ para você. Não houve repetições, tampouco comparações entre vogais orais e nasais, pois o objetivo foi comparar visualmente os espectrogramas das palavras em que as vogais nasais eram seguidas de consoantes oclusivas com aquelas em que tais vogais eram seguidas de fricativas. O resultado ver-se-á a seguir ${ }^{10}$.

Figura 7: (a) Pinta E (b) Pincha: Em (a), Entre As Linhas Pontilhadas Visualiza-Se o Murmúrio, Antes Deste, a Vogal NasAl e Depois Deste O SilÊNCIO DA Oclusiva; EM (B), A Linha Pontilhada Traça UMA FRONTEIRA ENTRE A VOGAL NASAL E A FRICATIVA.
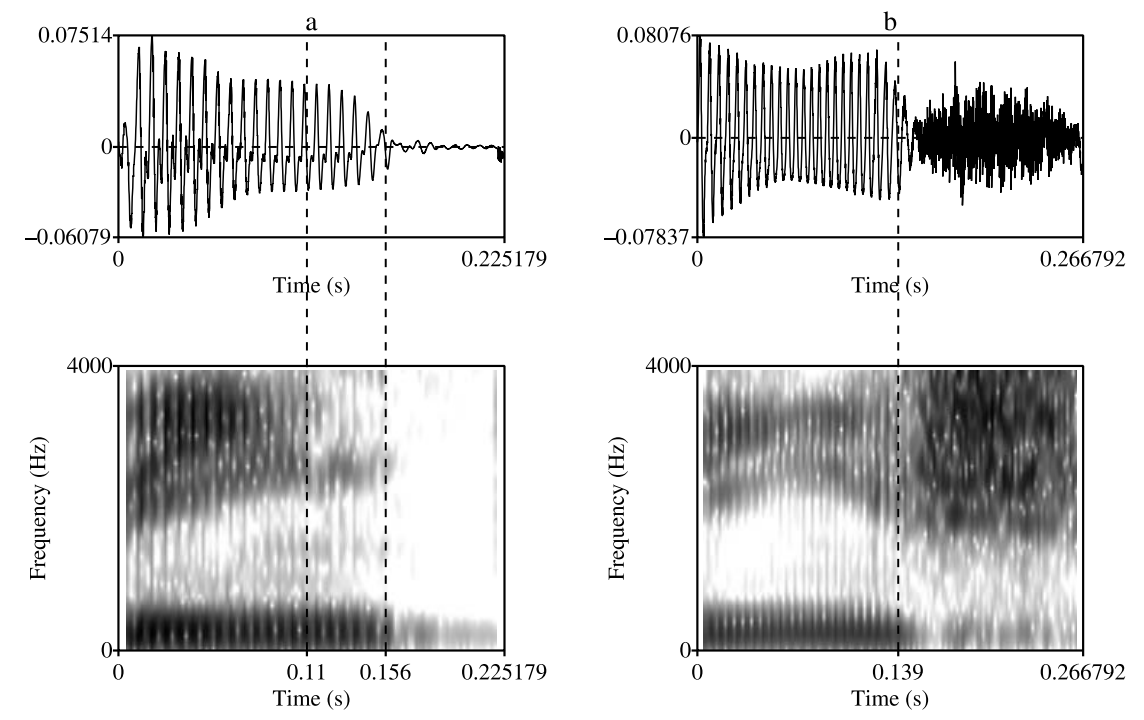

$10 \quad$ Foram escolhidos as formas de onda e os espectrogramas de apenas um par de palavras para cada vogal nasal investigada, seguida de consoante oclusiva e fricativa, por uma questão de espaço. Os pares apresentados são, no entanto, muito representativos do fenômeno encontrado. 
FIgURA 8: (a) CANTA E (b) DANÇA: EM (a), ENTRE AS LinHAS PONTILHADAS VisuAlizA-SE o MuRMÚRIo, ANTES DESTE, A VogAl NASAl E DEPOIS DESTE O SILÊNCIO DA OCLUSIVA; EM (b), A LINHA PONTILHADA DA FORMA DE ONDA ATÉ o ESPECTROGRAMA INDICA FrontEIRA ENTRE A VogAl E A FricATIVA; A Linha PontilHadA Do EsPeCTROGRAMA EM 100 MS (0.1) INDICA A INTERRUPÇÃO DE F3 E F4, ANTES DO FINAL DA VOGAL.
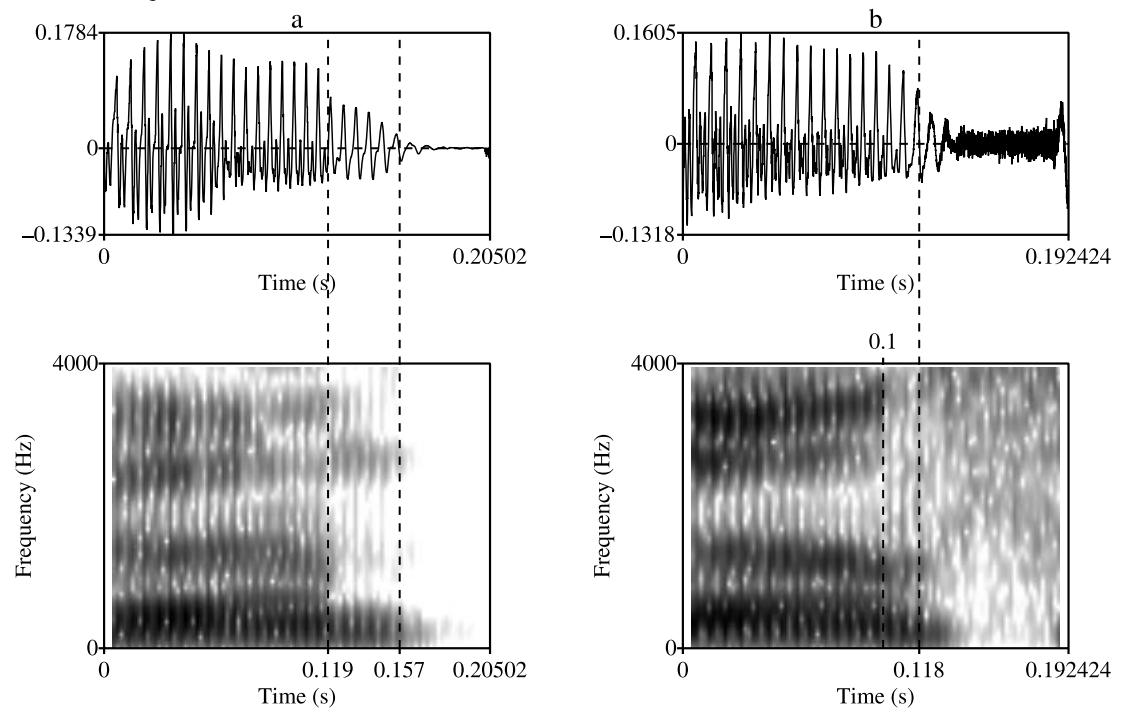

Figura 9: (a) Cumpre E (b) Punge: EM (a), Entre as Linhas Pontilhadas VisualizA-SE o MuRMúrio, ANTEs Deste, A Vogal NASAl E DEPOIS DESTE O SILÊNCIO DA OCLUSIVA; EM (b), A LINHA PONTILHADA DA FORMA DE ONDA ATÉ o ESPECTROGRAMA INDICA FRONTEIRA ENTRE A VOGAL E A FRICATIVA; A LINHA PONTILHADA DO ESPECTROGRAMA EM 106 MS INDICA A TRANSIÇÃo DA Vogal Nasal Posterior Para A Fricativa Palatal.
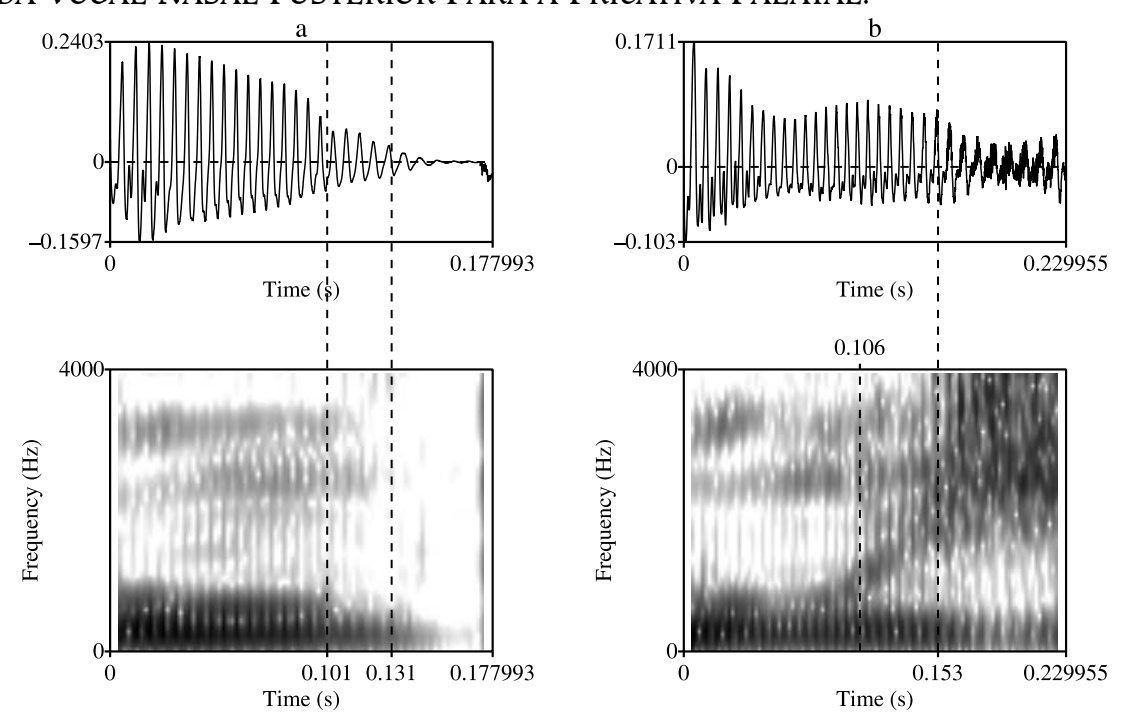
o murmúrio nasal, comumente investigado como traço acústico das consoantes nasais, é caracterizado articulatoriamente pelo abaixamento do véu palatino e pela oclusão do trato oral e acusticamente pela presença de formantes nasais, sendo o primeiro o mais reforçado em energia em torno de $300 \mathrm{~Hz}$ (FUJIMURA, 1962) e os demais bastante amortecidos. Seara (2000) descreve o murmúrio vocálico das cinco vogais nasais do PB, atribuindo-lhe de 3 a 5 formantes nasais (FN), dependendo da vogal. O FN1 médio mais baixo é de $200 \mathrm{~Hz}$, enquanto os demais variam desde $800 \mathrm{~Hz}$ até $3400 \mathrm{~Hz}$, o que está de acordo com o padrão formântico proposto por Fant (1960) para as consoantes nasais de um modo geral.

No presente estudo, todas as outras palavras contendo vogais nasais seguidas de fricativas tiveram a forma de onda e o espectrograma inspecionados visualmente e verificou-se que não apresentavam o murmúrio. Por outro lado, junto às vogais seguidas de oclusiva, o murmúrio fica patente. o único caso em que houve um lapso de tempo, entre a vogal e a fricativa, apresentando interrupção de formantes, foi o da vogal [ [ ] de dança (Figura 8). Ainda, para estas reflexões sobre a vogal nasal em PB, não realizamos medidas de duração e formantes para o murmúrio ${ }^{11}$, mas temos em Sousa (1994) que a duração do murmúrio vocálico ocupa de 20 a $65 \%$ da duração total da vogal nasal, o que se coaduna com a duração dos murmúrios seguidos de consoantes oclusivas nas figuras 7,8 e $9^{12}$.

\section{Discussão Final e Proposta de Uma Abordagem DinÂmica da VOGAL NASAL EM PB}

As reflexões propostas neste trabalho partiram da compreensão da realização fonético-acústica da vogal nasal em PB e apontaram para sua grande variabilidade. Vimos sobretudo que não se trata de variabilidade de uma classe de sons, mas também de variabilidade entre membros desta classe. Como apontado anteriormente, este é um fenômeno fonético universal: a vogal baixa se nasaliza mais facilmente que as demais. Ainda assim, vimos que a fase inicial das vogais nasais altas não pode ser considerada uma mera realização de pulsos orais. O que está em jogo, então, são ajustes do trato vocal para que o gesto fônico em questão dê conta da qualidade vocálica e de sua nasalidade.

\footnotetext{
Há um trabalho em andamento "A nasalidade em PB e a questão da coda vogal ou consoante?", no qual analisar-se-á o murmúrio vocal e os fenômenos de coarticulação em suas bordas, envolvendo medidas de duração e formantes.

12 De fato, a partir dos pontos encontrados no eixo do tempo para segmentar o murmúrio, temos a duração total da vogal e a do murmúrio, assim, foi possível calcular o seguinte: em pinta, o murmúrio ocupa $29 \%$ da vogal total, em canta, $24 \%$, e em cumpre, $23 \%$.
} 
Em sua borda direita, vimos que o murmúrio nasal está presente em contextos de consoante oclusiva e ausente em contextos de consoante fricativa. A explicação fonética para tanto está no fato de que para a produção das fricativas há uma maior ou menor constrição do trato vocal, mas a passagem de ar não é interrompida, ao contrário, permitindo a manutenção do acoplamento de tubos e por conseguinte a manutenção das ressonâncias orais e nasais. Neste caso, não se pode atribuir ao murmúrio vocálico uma característica de fase obrigatória da vogal nasal, já que ele depende do contexto silábico.

Diante da impossibilidade de atribuir fases precisas às vogais nasais do PB de uma maneira geral, propomos o tratamento do fenômeno sob a ótica da Fonologia Articulatória (FAR) (BROWMAN; GOLDSTEIN, 1989 e 1992, GOLDSTEIN; FOWLER, 2003) que permite ver o gesto da vogal nasal como um gesto complexo. Para a FAR, a unidade fonológica é o gesto articulatório e sua representação deve contemplar sua natureza dinâmica, ou seja, não há representações categóricas do tipo apagamento ou inserção de um segmento. Assim, a FAR propõe representar a sobreposição de gestos articulatórios, como por exemplo, a sobreposição do murmúrio nasal vocálico (gesto vélico) ao silêncio da oclusiva (gesto de fechamento). Os gestos estão relacionados a seis órgãos articulatórios que são representados verticalmente na pauta gestual. Tais órgãos são: lábios, ponta da língua, corpo da língua, raiz da língua, véu palatino e laringe. O exemplo da pauta, abaixo, demonstra como pode-se representar a sobreposição de gestos na palavra "team" (equipe), do inglês.

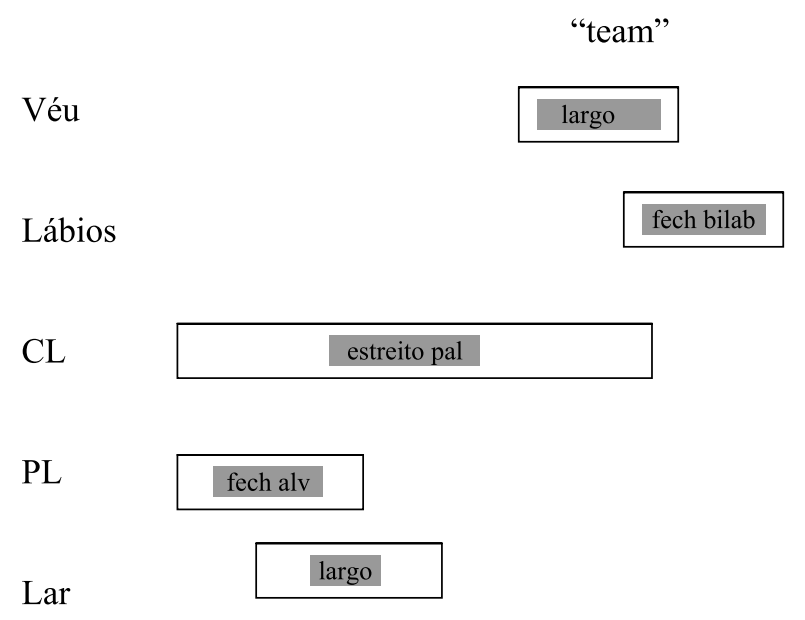

A figura acima foi adaptada a partir de Goldstein \& Fowler (2003). Trata-se da pauta gestual para a palavra "team". Os retângulos indicam o tempo em que o órgão responsável pelo gesto está ativado. Note-se como os gestos de CL (corpo da língua) e Véu se sobrepõem, indicando nasalização parcial da vogal anterior alta. 
A adequação da FAR para tratar o fenômeno da nasalidade vocálica em PB se torna ainda mais evidente, uma vez que podemos contar com o conceito de constelação gestual (BROWMAN; GOLDSTEIN, 1992), para o qual dois articuladores estão em jogo para determinar o gesto: este é o caso das vogais nasais do PB. Propomos que a nasalidade vocálica possa e deva ser descrita e explicada como um gesto complexo em que existe a sobreposição do gesto da abertura vélica ao da altura da língua, sendo este último o responsável pela qualidade vocálica desejada. Assim sugerimos a pauta gestual abaixo para a palavra canta:

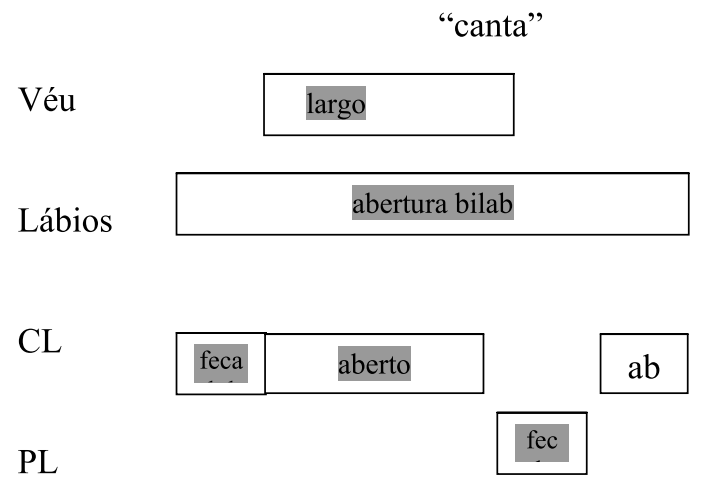

Na figura acima, interessa-nos destacar que o gesto vélico se ativa desde o início da vogal nasal, e parece se prolongar, sobrepondo-se ao gesto da oclusiva, o que pode estar sendo indicado a partir dos dados acústicos. O corpo da língua é o órgão responsável pelo gesto vocálico e o véu, o órgão responsável pelo gesto vélico, abaixado neste caso (wide).

Pelo que nos foi permitido compreender a partir dos dados acústicos das vogais nasais, parece lícito dizer que a exata configuração do trato para atingir uma determinada qualidade vocálica e a instalação gradual da nasalidade são muito importantes para atingir a distintividade fonológica. Estudos perceptuais envolvendo segmentação das vogais nasais (sobretudo as médias altas e as altas) verificaram que suas fases iniciais são ouvidas como orais (CAGLIARI, 1977; SEARA, 2000; MEDEIROS, 2006), o que entra em conflito com os achados do primeiro estudo deste trabalho. No entanto, as pistas acústicas de produção a partir das quais é possível inferir a articulação, no caso, o abaixamento do véu palatino, não estabelecem necessariamente uma isomorfia com as pistas acústicas de percepção. $O$ que supomos é que no momento preciso em que o gesto de altura da língua atinge seu alvo, o fluxo de ar nasal ainda não atingiu o seu máximo (muito embora o véu já tenha se abaixado), assim, ouve-se uma determinada vogal oral. 
Neste ponto das reflexões, outras questões se avizinham. Como seria a fronteira entre uma vogal nasal e uma vogal oral? As vogais nasais átonas seriam semelhantes às tônicas? Que respostas os dados aerodinâmicos nos poderiam dar a respeito das vogais nasais? Investigar o fenômeno da nasalidade vocálica a partir das questões levantadas é a tarefa que nos ensinará a dar elasticidade à hipótese mattosiana, e trabalhá-la à luz da FAR, podendo espichar para cá ou para lá a nasalidade vocálica, tímida no início de algumas vogais e persistente ao final, sobretudo quando há uma consoante oclusiva.

\title{
RESUMO
}

Este artigo propõe reflexões acerca do fenômeno da vogal nasal que versam desde a proposta bifonêmica para tratar tais vogais no português brasileiro, passando pela sua realização fonéticoacústica, até propor uma representação que leve em conta sua variabilidade. Embora as vogais nasais apresentem um comportamento formântico bastante regular em comparação às suas contrapartes orais, considerar o limite preciso entre dois fonemas ou mesmo duas fases (proposta bifásica, alternativa à bifonêmica) ainda permanece problemático. Assim, através da análise de espectros, a presença de uma fase genuinamente oral no início da vogal nasal é questionada. Foca-se, ainda, a questão do murmúrio nasal vocálico, facilmente encontrado junto a contextos silábicos em que a vogal nasal é seguida de consoante oclusiva, mas ausente quando seguida de consoante fricativa. Conclui-se que a natureza variável da vogal nasal será melhor tratada sob uma perspectiva dinâmica, encontrada junto à Fonologia Articulatória. Propõe-se então, uma primeira aproximação da problemática das vogais nasais com a abordagem dinâmica.

Palavras-chave: vogais nasais; Fonética; Fonologia.

\begin{abstract}
This articles proposes a reflection about the nasal vowel phenomenon in Brazilian Portuguese by analyzing the biphonemic proposal and acoustic phonetic production features to propose a representation which is able to capture its variability. Although nasal vowels have formant patterns as regular as their oral counterparts, it remains difficult to estimate the precise limit between two phonemes or even two phases (biphasic proposal, an alternative to thebiphonemic proposal). In this way, the existence of a purely oral portion in the
\end{abstract}


beginning of the vowel is called into question. Also discussed is the variable nature of the nasal murmur, usually present in syllabic contexts in which the nasal vowel precedes an obstruent, but absent when it precedes a fricative. It can be concluded that the variable nature of the nasal vowel is better explained by a dynamical perspective as the one proposed by Articulatory Phonology. Finally, a first approximation of the treatment of nasal vowels is proposed with the dynamical approach.

Key-words: nasal vowels; Phonetics; Phonology.

\section{REFERÊNCIAS}

ABAURRE, B. M.; PAGOTTO, E. G. Nasalização vocálica no português do Brasil. In: KOCH, I. G. V. Gramática do português falado. Campinas: Editora da Unicamp, 1996. v. VI. p. 495526.

AMELOT, A.; MiCHAUD, A. Effets aérodynamiques du mouvement du velum: le cas de voyelles nasales du français. Journées d'Etudes sur la Parole (JEP), p. 247-250, 2006.

BATTISTI. E. A nasalização do português brasileiro pela teoria da otimidade. Rev. Est. Ling., 7, n. 1, p. 59-89, 1998.

BROWMAN, C.; GOLDSTEIN, L. Articulatory gestures as phonological units. Phonology yearbook, 6, p. 201-251, 1989.

. Articulatory Phonology: an overview. Phonetica, 49, p. 155-180, 1992.

BISOL. L. Estudo sobre a nasalidade. In: ABAURRE, B. (Org.). Gramática do português falado. Campinas: Editora da Unicamp, 2002. v. VIII. p. 501-535.

CAGLIARI, L. C. An experimental study of nasality with particular reference to Brazilian Portuguese. 320 f. Tese (Doutorado) - University of Edinburgh, Edinburgo, 1977.

CÂmARA JR., J. M. Problemas de lingüística descritiva. Petrópolis: Editora Vozes, 1971. . Estrutura da língua portuguesa. 12. ed. Petrópolis: Editora Vozes, 1982.

CLUMECK, H. Patterns of soft palate movements in six languages. Journal of Phonetics, 4, p. 337-351, 1976.

DELVAUX, V. Contrôle et connaisance phonétique: les voyelles nasales du français. Tese (Doutorado) - Université Libre de Bruxelles, Bruxelas, 2003.

GOLDSTEIN, L.; FOWLER, C. Articulatory Phonology: a phonology for public language use. In: SCHILlER, N.O.; MEYER, A. S. (Orgs.). Phonetics and Phonology in Language Comprehension and Production. Mouton de Gruyter, 2003. p. 159-207.

FUJIMURA, O. Analysis of nasal consonats. J. of the Ac. Soc. of America, 34, n. 12, p. 1865$1875,1962$.

JESUS, M. de S. V. Estudo fonético da nasalidade vocálica. Estudos Lingüísticos 5: estudos em fonética e fonologia do português, p. 205-224, 2002.

KENT, R., CARNEY, P.; SEVEREID, L. R. Velar movement and timing: evaluation of a model of binary control. J. Speech Hearing Res., p. 17: 470-488, 1974. 
MEdeIRos, B. R. de. Vogais Nasais do Português Brasileiro...

MEDEIROS, B. Raposo de. Percepção das diferentes fases de vogais nasais do português brasileiro: estudo preliminar. In: 54 SEMINÁRIO DO GEL, Araraquara, UNESP, 2006.

MEDEIROS, B. R. de; DEMOLIN, D. Vogais nasais no português brasileiro: um estudo de IRM. In IV CONGRESSO INTERNACIONAL DA ABRALIN, Brasília, 2005.

MORAES, J. A.; WETZELS, L. Sobre a duração dos segmentos vocálicos nasais e nasalizados em português. Cad. Est. Ling., 23, p. 153-166, 1992.

MORAIS-BARBOSA, J. Les voyelles nasales portugaises: interprétation phonologique. In: ANTTI, S.; AALTO, P. PROC. FOURTH INTER. CONGRESS OF PHONETIC SCIENCES, p. 691$708,1962$.

OHALA, J.; OHALA, M. The phonetics of nasal phonology: theorems and data. Phonetics and phonology. Nasals, nasalization and the velum, n. 5, p. 225-249, 1993.

OLIVEIRA. C.; TEIXEIRA, Antonio. On gestures timing in european portuguese nasals. In: ICPhS XVI, Saarsbrüken, p. 405-408, 2007.

PARKINSON, S. Portuguese nasal vowels as phonological diphtongs. Lingua 61, p. 157$177,1983$.

QUICOLI, A. C. Harmony, lowering and nasalization in Brazilian Portuguese. Lingua 80, p. 295-331, 1990.

SEARA, I. C. Estudo acústico-perceptual da nasalidade das vogais do português brasileiro. 270 f. Tese (Doutorado) - Universidade Federal de Santa Catarina, Florianópolis, 2000.

SOUSA, E. M. G. Para a caracterização fonético-acústica da nasalidade no português do Brasil. Dissertação (Mestrado) - Universidade Estadual de Campinas, 1994.

STEVENS, K. N. Acoustic Phonetics. Cambridge, Londres: MIT Press, 2000.

USHIJIMA, T.; HIROSE, H. Eletromyographic study of the velum during speech. Journal of Phonetics 2, 4, p. 315-326, 1974. 